\title{
Carboxamido-substituted imidazoles from 1,2,3-tricarbonyl derivatives and acetamido-substituted thiazoles from 4-bromo-3-oxo-butanenitriles
}

\author{
Michal Weitman and Abraham Nudelman* \\ Chemistry Department, Bar Ilan University, Ramat Gan 52900, Israel \\ E-mail:nudelman@mail.biu.ac.il
}

\begin{abstract}
Carboxamido-substituted imidazoles obtained from 1,2,3-tricarbonyl compounds and acetamidosubstituted thiazoles from 4-bromo-3-oxo-butanenitriles are described.
\end{abstract}

Keywords: Imidazoles, thiazoles

\section{Introduction}

Imidazoles are common compounds which frequently possess therapeutic properties, a variety of which can be found in the Merck Index. ${ }^{1}$ In particular Cefpimazole ${ }^{2}$ and Dacarbazine ${ }^{3}$ are closely related to the substituted imidazoles discussed herein. In the course of investigations dealing with

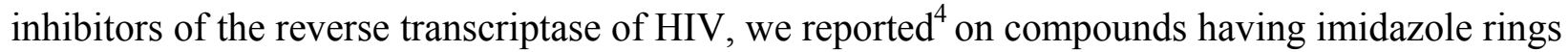
substituted with a carboxamido functionality, analogs of compound 1 (Figure 1), that were prepared using the Bredereck reaction of $\alpha$-bromoketones with formamide. ${ }^{5}$ In general carboxamido functional groups on an imidazole ring have been prepared by hydration of a nitrile substituent ${ }^{6}$ or by conversion of an ester into the corresponding amide. ${ }^{7}$ Herein we describe an approach for the preparation carboxamido-substituted imidazoles, involving a three-step sequence from 1,2,3-tricarbonyl reagents.

The initial targets of the reverse transcriptase inhibitors were compounds having an imidazole ring linked directly to a phenyl ring and hence expected to assume a relatively rigid planar conformation as a result of conjugation. Molecular modeling calculations suggested a tricyclic scaffold having a central phenylene ring substituted at the meta positions (1), however the calculations did not firmly establish the preferred distance linking the aromatic rings. ${ }^{4}$ To study compounds possessing a greater degree of flexibility and rotational freedom we aimed for analogs where the substituents on the phenylene $\mathbf{B}$ ring were distanced by one carbon atom (see 2, Figure 1). An additional goal of these studies was to synthesize isosteres of the imidazole ring, such as thiazoles, aminoimidazoles and aminothiazoles. 


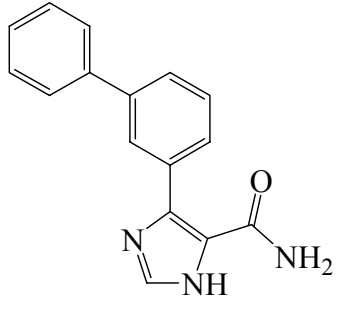

1

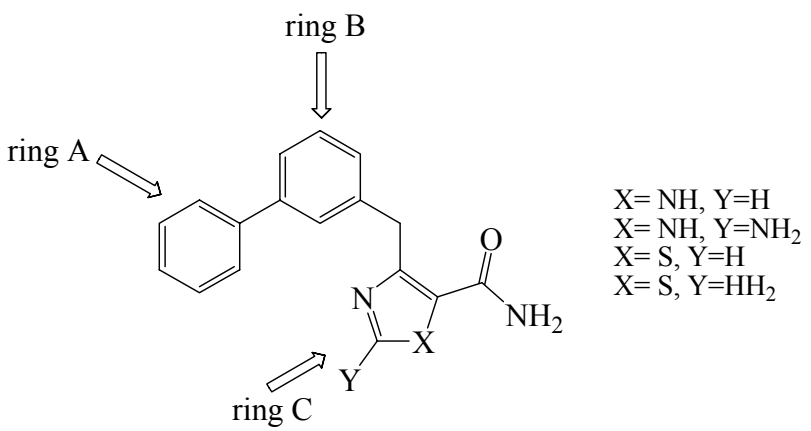

2

Figure 1. Tricyclic carboxamido substituted imidazoles.

In the retrosynthetic analysis compound I was expected to be generated by the Bredereck method from the corresponding $\alpha$-bromoketone II and formamide. The ketone II in turn would be the product of nitrile hydration of III followed by enol-bromination. Compound III was to be prepared in two steps involving condensation of the di-anion of cyanoacetic acid with a suitably activated meta-substituted-phenylacetic acid and attachment of the $\mathbf{A}$ aryl group (see Fig. 1) by a Suzuki-coupling reaction (Scheme 1).

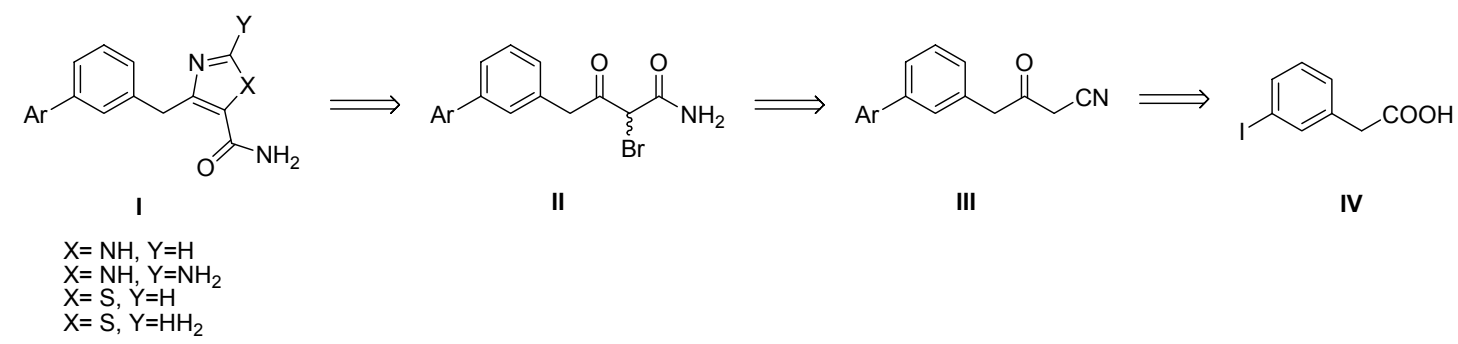

Scheme 1. Retrosynthetic analysis.

\section{Results and Discussion}

3-Iodophenylacetyl chloride $4{ }^{4}$ obtained from the acid 3 a was treated with cyanoacetic acid in the presence of $\mathrm{n}$-BuLi to give the cynaomethyl ketone $\mathbf{5} \mathbf{a}^{4}$ which upon hydration in the presence of $\mathrm{H}_{2} \mathrm{SO}_{4}$ (conc.) gave amide $\mathbf{6 a}$, in about $18 \%$ yield. It is conceivable that the organic matter which remained in the aqueous solution was derived from aromatic sulfonation. ${ }^{8}$ However hydration of 5a in the presence of PPA (polyphosphoric acid) led to 6a in 50\% yield. Analogous manipulations were carried out with the $m-\mathrm{H}$ and $m$-Ph substituted compounds (Scheme 2). 


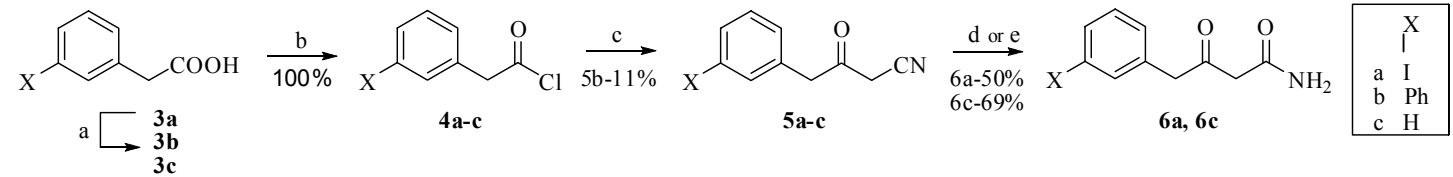

a) $\mathrm{PhB}(\mathrm{OH})_{2}, \mathrm{H}_{2} \mathrm{O}, \mathrm{NaOH}, \mathrm{Pd}(\mathrm{OAc})_{2}$; b) oxalyl chloride, DMF (cat.), $\mathrm{CH}_{2} \mathrm{Cl}_{2}$; ; c) cyanoacetic acid, n-BuLi, THF, $-78^{\circ} \mathrm{C}, \mathrm{H}_{2} \mathrm{O}$; d) $\mathrm{H}_{2} \mathrm{SO}_{4}$; e) PPA, $120{ }^{\circ} \mathrm{C}$

Scheme 2. Synthesis of $\beta$-ketoamides.

In 3-oxo-4-phenylbutanamides $\mathbf{6}^{9}$ both methylenes are potentially reactive towards bromination, one because it is benzylic and the other because it is part of a $\beta$-dicarbonyl system. To determine the position at which the bromination step would take place, $\mathbf{6 c}$ was used as a model. When bromination was carried out in the presence of one equivalent of $\mathrm{CuBr}_{2}$, after $1 \mathrm{~h}$, a major product was detected by tlc mixed with a minor amount of starting material, however all attempts to isolate any product(s) 7 of the reaction failed presumably because of their expected high reactivity (Scheme 3 ).

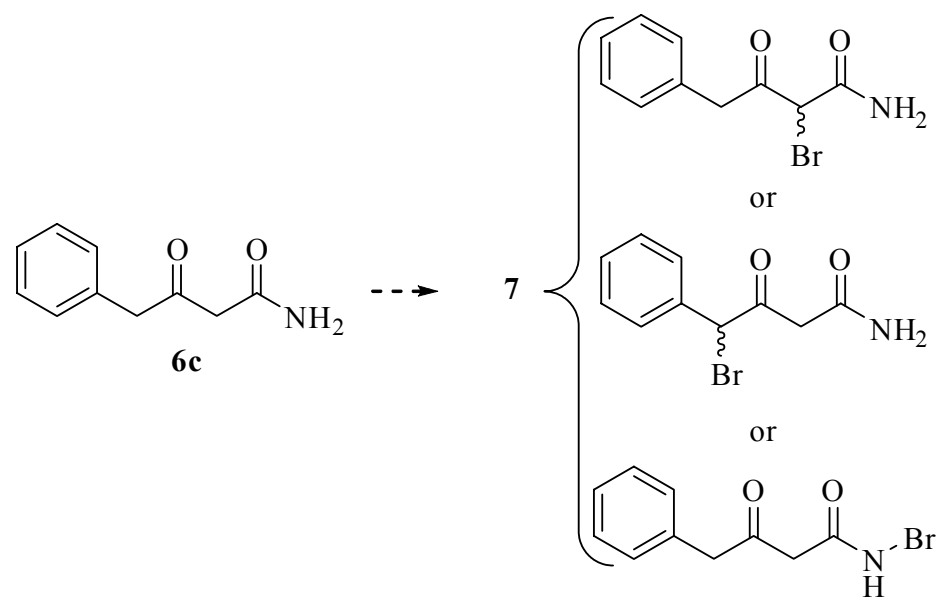

Scheme 3. Possible reactive products of $\beta$-ketoamide bromination.

In view of the failure to brominate $\mathbf{6 c}$, the reaction was repeated with the cyanomethyl ketone $\mathbf{5} \mathbf{c}^{10}$ where the hydration step was delayed to a later stage. In this case the bromination took place at the benzylic position to give compound $\mathbf{8}$, apparently, due to a preferred enol formed in conjugation with the aromatic ring. Although $\mathbf{8}$ was the undesired brominated isomer, it was further used in the preparation of compounds 9, 11 and 12 (Scheme 4) isomeric to our target compounds (see Figure 2) and which could assist in structure activity relationship (SAR) studies. Compound 9 was readily prepared by reaction with thiourea, however, attempted hydration of the nitrile group in the presence of hydrogen peroxide and base to give 10, failed. Deamination of the amino-thiazole group in the presence of sulfuric acid/ $\mathrm{NaNO}_{2}$, gave the thiazole 11, without any sign of nitrile hydration which could have conceivably taken place when 9 was initially 
exposed to the aqueous sulfuric acid. Subsequent exposure of $\mathbf{1 1}$ to hydration conditions in concentrated $\mathrm{H}_{2} \mathrm{SO}_{4}$ gave amide 12. Attempted conversion of $\mathbf{8}$ into imidazole $\mathbf{1 3}$ under Bredereck reaction conditions failed.

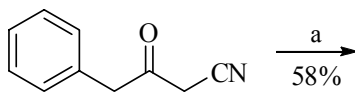

$5 c$

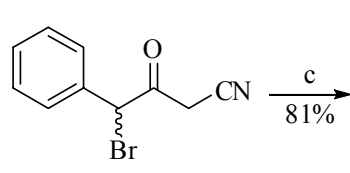

$\mathrm{xb}$

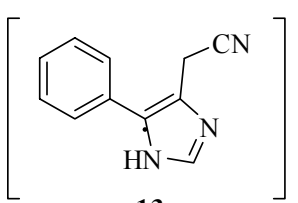

13
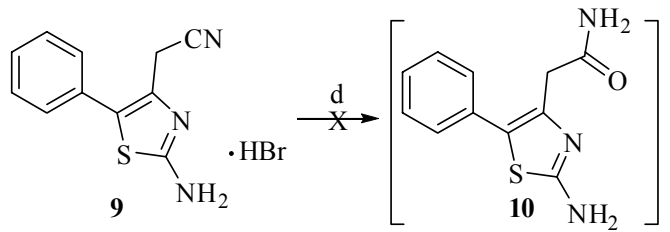

$9.5 \% \downarrow \mathrm{e}$

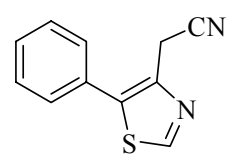

11

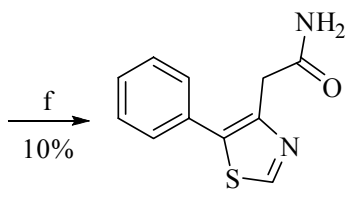

12

a) $\mathrm{CuBr}_{2}$, EtOAc, reflux; b) formamide or formamide/ $\mathrm{H}_{2} \mathrm{SO}_{4}$ (cat.), 160 oC; c) thiourea, EtOH; d) $\mathrm{H}_{2} \mathrm{O}_{2} 30 \%, \mathrm{NH}_{4} \mathrm{OH} / \mathrm{MeOH}$; e) $\mathrm{H}_{2} \mathrm{SO}_{4} 40 \%, \mathrm{NaNO}_{2}, \mathrm{H}_{2} \mathrm{O}, \mathrm{Ca}\left(\mathrm{H}_{2} \mathrm{PO}_{2}\right)_{2} / \mathrm{H}_{2} \mathrm{O}, 0{ }^{\circ} \mathrm{C}$; f) $\mathrm{H}_{2} \mathrm{SO}_{4}$ (conc.)

Scheme 4. Thiazoles from $\beta$-ketonitriles.

In view of our inability to prepare the target imidazoles by the Bredereck reaction, an alternative approach was undertaken. The synthesis of imidazoles from 1,2-dicarbonyl compounds is well known. ${ }^{11}$ Since in our case the final imidazolic compound is substituted by an amide group, it was necessary to initiate the synthesis with the contiguous hydrated tricarbonyl derivative 17a. When this compound was allowed to stand overnight in an acetone- $d_{6}$ solution it dehydrated and was detected in the NMR as the corresponding enol 18a. The synthesis of the tricarbonyl system (hydrated or dehydrated) required only two steps, and was initially carried out with benzaldehyde $\mathbf{1 4 a}$ as a model compound. The two first steps, $\mathbf{1 4 \rightarrow \mathbf { 1 7 }}$ are known ${ }^{12}$ and both proceeded in $\sim 90 \%$ yields. The first one involved a condensation between glyoxal, cyanide and benzaldehyde followed by mild hydrolysis using acidic amberlite leading to the tricarbonyl species 17a-18a. The structure of intermediate 15b was established by extensive NMR experiments including Cosy, HMQC and HMBC. We think that the structure of the heterocycle in compound $\mathbf{1 5 b}$ is unambiguously determined by the carbon chemical shifts and by the $\mathrm{CH}$ correlations observed in the HMBC two-dimensional spectrum (typically 2- and 3-bond coupling interactions may be detected), as shown in Fig. 2. In the Figure, the interactions are shown as $\mathrm{C} \rightarrow \mathrm{H}$. Notice that cross-peak between the $\boldsymbol{C}-\mathrm{NH}_{2}$ and the ring $\mathrm{CH}$ indicates that a cycle has indeed been formed. 


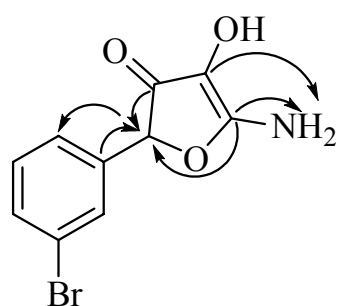

Figure 2. $\mathrm{CH}$ correlations observed in the HMBC.

Although the reported ${ }^{13}$ treatment of 1,2-dicarbonyl compounds with guanidine leads to aminoimidazoles, in our case treatment of 17a-18a with guanidinium hydrochloride, guanidine or thiourea, followed by hydrogenation using $\mathrm{H}_{2} / \mathrm{Pd}$ or ammonium formate did not afford the aminoimidazole nor the aminothiazole 19 (Scheme 5). Treatment of 17a-18a with hexamethylenetetramine/ammonium acetate in acetic acid at $65{ }^{\circ} \mathrm{C}$, led to decomposition products. However, using microwave irradiation ${ }^{14}$ or heating in an oil bath, both at $165^{\circ} \mathrm{C}$, led to the carboxamido substituted imidazole 20a. Although the various products are structurally similar each required special synthetic conditions. For example, the $m$-phenyl-substituted 15c was obtained in $30 \%$ yield since in this case the cyanohydrin derivative $\mathbf{1 6} \mathbf{c}^{15}$ also formed and was isolated in $70 \%$ yield. The reaction involved addition of cyanide to a mixture of two aldehydes, benzaldehyde and glyoxal. In the model case where benzaldehyde was used, apparently the glyoxal was more electrophilic and underwent preferential reaction with the cyanide, leading to a high yield of 15a. Whereas in the case of the $m$-phenylbenzaldehyde 14c which is more electrophilic than glyoxal the reaction led to the formation of the cyanohydrin 16c and a low yield of 15c. We assumed that pre-stirring of the glyoxal in the presence potassium cyanide without adding the 3-phenylbenzaldehyde 14c would prevent the formation of the byproduct 16c, but even with initial stirring (for about $0.5 \mathrm{~h}$ ), the amount of $\mathbf{1 6 c}$ was not reduced. Hydrolysis of $15 \mathrm{c}$ even after $5 \mathrm{~h}$ ( $1.5 \mathrm{~h}$ in the model) gave $30 \%$ yield of $17 \mathrm{c}-18 \mathrm{c}$ ( $70 \%$ in the model). The low yield was attributed to the poor aqueous solubility of $\mathbf{1 5 c}$. As an alternative approach to 20c, it was considered plausible to initiate the synthesis from $m$-bromobenzaldehyde 14b (using the halogen as a handle for a Suzuki coupling) which was converted in high yield into 16b, however, attempts to convert the latter into the "tricarbonyl" derivative 17b-18b, even under exhaustive hydrolytic conditions, gave a mixture of starting material $\mathbf{1 6} \mathbf{b}$ together with the desired 17b-18b. 


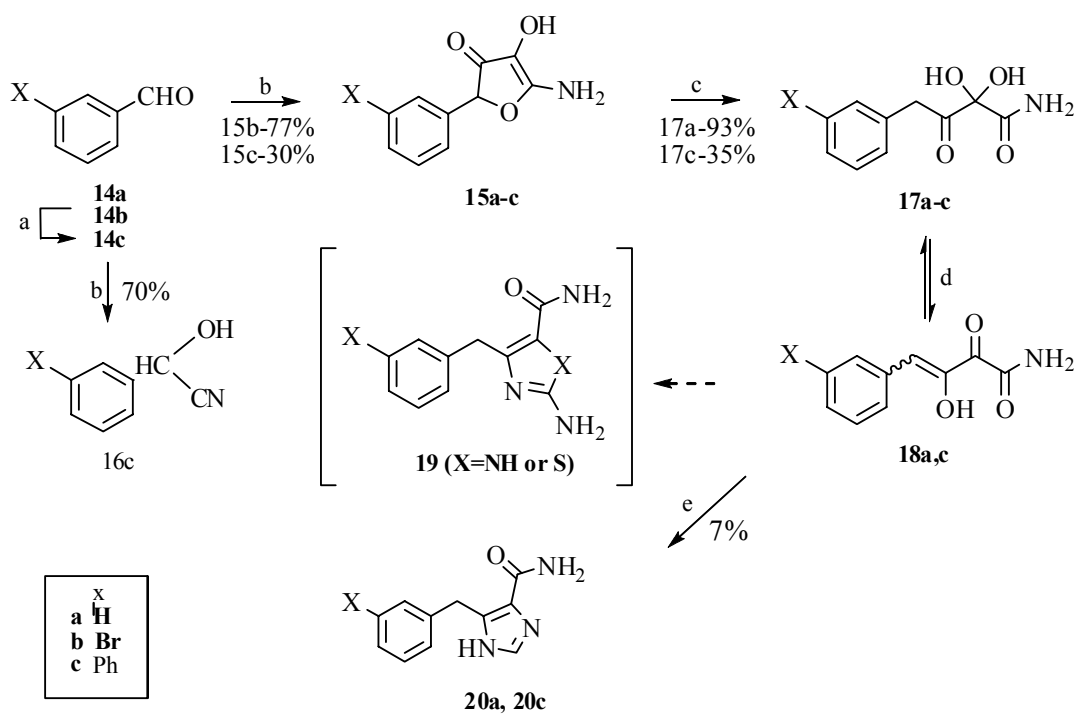

\begin{abstract}
a) Phenylboronic acid, $\mathrm{PdCl}_{2}, \mathrm{~K}_{2} \mathrm{CO}_{3}, \mathrm{EtOH}, \mathrm{Bu}_{4} \mathrm{NBr}$; b) $\mathrm{KCN}, \mathrm{Na}_{2} \mathrm{CO}_{3}$, glyoxal bis(sodium hydrogen sulf ite), dioxane, AcOH; c) Amberlite IR $120\left(\mathrm{H}^{+}\right.$-form), $\mathrm{H}_{2} \mathrm{O}$; d) $\mathrm{H}_{2} \mathrm{O}$; e) hexamethylenetetramine/ $\mathrm{NH}_{4} \mathrm{OAc}, \mathrm{AcOH}$, microwave irradiation or $165^{\circ} \mathrm{C}$
\end{abstract}

Scheme 5. Synthesis of carboxamido-substituted imidazoles.

Alternative pathways for the ring opening of $\mathbf{1 5}$ to give the hydrated tricarbonyl species $\mathbf{1 7}$ are shown in Scheme 6.

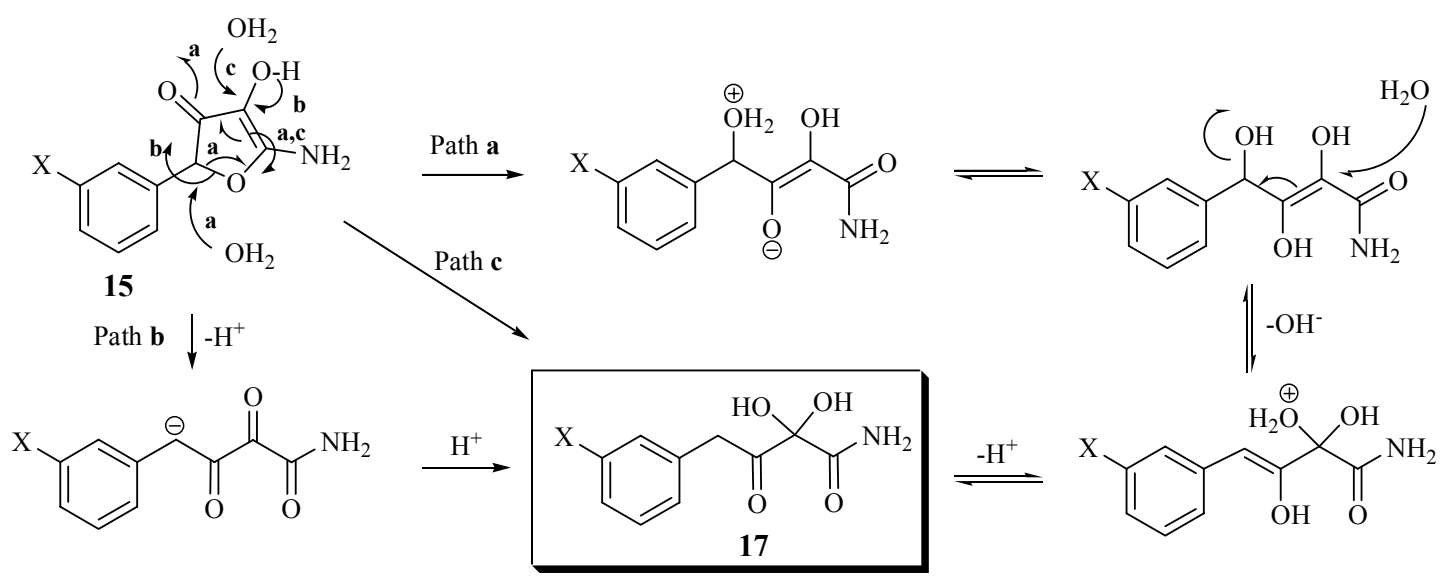

Scheme 6. Hydrolysis paths of 5-amino-4-hydroxy-2-phenylfuran-3(2H)-ones. 


\section{Conclusions}

The synthesis of carboxamido-substituted imidazoles obtained from 1,2,3-tricarbonyl compounds and acetamido-substituted thiazoles from 4-bromo-3-oxo-butanenitriles, were developed.

\section{Experimental Section}

General Procedures. ${ }^{1} \mathrm{H}$ and ${ }^{13} \mathrm{C}$ NMR spectra 200,300 and $600 \mathrm{MHz}$ were obtained on Bruker AC-200 and AM-300 spectrometers, respectively. Chemical shifts are expressed in ppm downfield from $\mathrm{Me}_{4} \mathrm{Si}$ used as internal standard. The values are given in $\delta$ scale. Mass spectra were obtained on a Varian Mat 731 spectrometer $(\mathrm{CI}=$ chemical ionization). HRMS were obtained on a VG AutoSpec E spectrometer. Progress of the reactions was monitored by TLC on silica gel (Merck, Art. 5554) or alumina (Riedel-de Haen, Art. 37349). Flash chromatography was carried out on silica gel (Merck, Art. 9385). The microwave experiments were carried out using a Biotage Initiator EXP EU instrument, at a maximum power of $300 \mathrm{~W} /$ frequency 2450 MHz. Commercially available compounds were used without further purification.

4-(Biphenyl-3-yl)-3-oxobutanenitrile (5b). Compound 5b was obtained as a white solid in $11 \%$ yield from compound $\mathbf{4 b}$ using the reported general procedure for the synthesis of cyanoacetonitriles. ${ }^{4}{ }^{1} \mathrm{H}$ NMR $\left(300 \mathrm{MHz}\right.$, acetone- $\left.d_{6}\right): \delta 4.03\left(\mathrm{~s}, 2 \mathrm{H}, \mathrm{CH}_{2} \mathrm{CN}\right), 4.05(\mathrm{~s}, 2 \mathrm{H}$, $\left.\mathrm{ArCH}_{2}\right), 7.22-7.68(\mathrm{~m}, 9 \mathrm{H}, \mathrm{Ar}) .{ }^{13} \mathrm{C}$ NMR $\left(300 \mathrm{MHz}\right.$, acetone- $\left.d_{6}\right) \delta 32.2\left(\mathrm{CH}_{2} \mathrm{CN}\right), 49.0$ $\left(\mathrm{ArCH}_{2}\right), 115.3(\mathrm{CN}), 126.4,127.8,128.3,129.4,129.65,129.7,129.9,136.9,141.6,142.2,197$ (CO). MS (CI+) m/z (\%): $235.10\left(\mathrm{M}^{+}, 19.5\right)$. HRMS: calcd. for $\mathrm{C}_{16} \mathrm{H}_{13} \mathrm{NO}$ 235.0997; found 235.1007

4-(3-Iodophenyl)-3-oxobutanamide (6a). A mixture of $\mathbf{5 a}^{4}(0.12 \mathrm{~g}, 0.75 \mathrm{mmol})$ and polyphosphoric acid (PPA) $(0.29 \mathrm{~g})$ was heated at $110-130{ }^{\circ} \mathrm{C}$ for $1 \mathrm{~h}$. The mixture was poured into ice cold water, stirred for $0.5 \mathrm{~h}$, was then slowly basified with solid $\mathrm{NaHCO}_{3}$ to $\mathrm{pH} \sim 9$, and finally extracted with EtOAc. The organic phase was separated, dried $\left(\mathrm{MgSO}_{4}\right)$, filtered and evaporated to give 6a as a mixture of ketone and enol forms (1:1.9), as a yellow solid in $50 \%$ yield. The NMR data assignment was aided by several two-dimensional spectra including COSY, HMQC and HMBC analysis. ${ }^{1} \mathrm{H}$ NMR $\left(600 \mathrm{MHz}\right.$, acetone- $\left.d_{6}\right): \delta$ 7.93-8.00 (m, $2 \mathrm{H}, H-\mathrm{C} 2$ (ket), $H$-C6 (ket)), 7.74-7.76 (m, 1H, $H$-C2 (enol)), 7.69-7.72 (dt, 1H, $J=6.9 ; 2.1 \mathrm{~Hz}, H$-C6 (enol)), 7.63-7.67 (ddd, $1 \mathrm{H}, J=8.1 ; 2.1 ; 1.2 \mathrm{~Hz}, H$-C4 (ket)), 7.58-7.53 (t, $1 \mathrm{H}, J=7.8 \mathrm{~Hz}, H$-C5 (ket)), 7.49-7.44 (m, 2H, $H$-C4 (enol), $H$-C5 (enol)), 7.12 (bs, $1 \mathrm{H}, N H$ (ket/enol)), 6.68-6.52 (bs, 1H, $\mathrm{NH}$ (ket/enol)), 5.9 (s, 1H, $\mathrm{CH}$ (enol)), 3.96 (s, 2H, $\mathrm{CH}_{2}$ (ket)). ${ }^{13} \mathrm{C}$ NMR $(600 \mathrm{MHz}$, acetone- $\left.d_{6}\right)$ : $\delta 194.12(C O($ ket $)), 175.47$ (CON (ket)), 169.02 (CON(enol)), 139.52 (C1 (ket)), 137.55 (C1 (enol)), 135.12 (C3 (ket)), 134.99 (C3 (enol)), 133.77 (C4 (ket)), 131.26 (C2 (ket)), 131.18 (C4 (enol)), 131.13 (C2 (enol)), 129.1 (C6 (ket)), 127.94 (C5(ket)), 126.2 (C6 (enol)), 
124.78 (C5 (enol)), 89.73 ( $\mathrm{CH}$ (enol)), 47.42 ( $\mathrm{CH}_{2}$ (ket)). MS (CI+) $m / z(\%): 197.03 ; 198.03$ $\left(\mathrm{M}^{+}, 100 ; 85\right)$. HRMS: calcd. for $\mathrm{C}_{9} \mathrm{H}_{8} \mathrm{NO}_{2} \mathrm{Cl}\left(\mathrm{M}^{+}, \mathrm{CI}+\right)$ 197.024; found 197.027.

3-Oxo-4-phenylbutanamide (6c). ${ }^{9}$ Using the same procedure as that used in the synthesis of $6 \mathbf{b}$, compound $\mathbf{6 c}$ was obtained in $69 \%$ yield as a cream colored solid from $5 \mathbf{c} .{ }^{1} \mathrm{H}$ NMR $(300 \mathrm{MHz}$, $\mathrm{CDCl}_{3}$ ): $\delta 3.36\left(\mathrm{~s}, 2 \mathrm{H}, \mathrm{CH}_{2} \mathrm{CONH}_{2}\right.$ ), 3.72 (s, 2H, $\mathrm{ArCH}_{2}$ ), 5.83 (bs, $\left.1 \mathrm{H}, \mathrm{NH}\right), 6.89$ (bs, 1H, NH), $7.13(\mathrm{~m}, 5 \mathrm{H}, \mathrm{Ar}) .{ }^{13} \mathrm{C} \mathrm{NMR}\left(300 \mathrm{MHz}, \mathrm{CDCl}_{3}\right): \delta 47.92,50.96\left(\mathrm{CH}_{2} \mathrm{CONH}_{2}\right.$ and $\left.\mathrm{ArCH}\right), 127.73$ (C-4), 129.16, 129.73 (C-2 and C-3), 131.98 (C1), $168.26\left(\mathrm{CONH}_{2}\right), 204.15(\mathrm{CO}) . \mathrm{MS}(\mathrm{CI}+) \mathrm{m} / z$ (\%): $177.08\left(\mathrm{M}^{+}, 15\right), 118.04\left(\mathrm{BnCO}^{+}, 37.15\right)$. HRMS: calcd. for $\mathrm{C}_{10} \mathrm{H}_{11} \mathrm{NO}_{2}$ 177.0790; found 177.0756 .

4-Bromo-3-oxo-4-phenylbutanenitrile (8). A mixture of $\mathbf{5 c}^{\mathbf{1 0}}(0.14 \mathrm{~g}, 0.85 \mathrm{mmol})$ and $\mathrm{CuBr}_{2}$ $(0.2 \mathrm{~g}, 0.85 \mathrm{mmol})$ in anhydrous EtOAc $(20 \mathrm{~mL})$ was heated to reflux for $3.5 \mathrm{~h}$. The mixture was cooled and filtered through a short silica column. The filtrate was evaporated and the residue was purified by flash chromatography (hexane:EtOAc $3: 1$ ) to give 8 as a yellow oil in $58 \%$ yield. ${ }^{1} \mathrm{H}$ NMR (300 MHz, $\left.\mathrm{CDCl}_{3}\right): \delta 3.77\left(\mathrm{ABq}, J=14 \mathrm{~Hz}, 2 \mathrm{H}, \mathrm{CH}_{2} \mathrm{CN}\right), 5.6(\mathrm{~s}, 2 \mathrm{H}, \mathrm{CHBr}), 7.41(\mathrm{~m}, 5 \mathrm{H}$, $\mathrm{Ar}) .{ }^{13} \mathrm{C}$ NMR $\left(300 \mathrm{MHz}, \mathrm{CDCl}_{3}\right): \delta 28.9\left(\mathrm{CH}_{2}\right), 53.4(\mathrm{CHBr}), 113.3(\mathrm{CN}), 128.9,129.42(\mathrm{C}-o$, C-m), 133.1 (CCHBr), 189.7 (CO). MS (CI+) m/z (\%): $239.99\left(\mathrm{MH}^{+}, 16.73\right), 237.99\left(\mathrm{MH}^{+}\right.$, 16.77), $211.99 \mathrm{M}^{+}\left(\mathrm{MH}^{+}-\mathrm{CN}, 48.59 \%\right) 209.99 \mathrm{M}^{+}\left(\mathrm{MH}^{+}-\mathrm{CN}, 48.59\right), 170.97\left(\mathrm{BnBr}^{+}, 32.55\right)$, $168.97\left(\mathrm{BnBr}^{+}, 33.67\right)$. HRMS: calcd. for $\mathrm{C}_{12} \mathrm{H}_{9} \mathrm{NO}^{81} \mathrm{Br} 239.9847$; found 239.9855, calcd. for $\mathrm{C}_{12} \mathrm{H}_{9} \mathrm{NO}^{79} \mathrm{Br} 237.9868$; found 237.9871

2-(2-Amino-5-phenylthiazol-4-yl)acetonitrile hydrobromide (9). Compound 9 was obtained as a white solid in $81 \%$ yield from $8(0.04 \mathrm{~g}, 0.16 \mathrm{mmol})$ using the reported general procedure for the synthesis of aminothiazoles, ${ }^{4} \mathrm{mp}$ (dec.) 207-209 ${ }^{\circ} \mathrm{C}$. The NMR data assignment was aided by several two-dimensional spectra including COSY, HMQC and HMBC analysis. ${ }^{1} \mathrm{H}$ NMR (600 $\left.\mathrm{MHz}, \mathrm{CD}_{3} \mathrm{OD}\right): \delta 3.93\left(\mathrm{~s}, 2 \mathrm{H}, \mathrm{CH}_{2}\right), 7.47(\mathrm{~m}, 2 \mathrm{H}, H-o), 7.54(\mathrm{~m}, 3 \mathrm{H}, H-m, H-p) .{ }^{13} \mathrm{C}$ NMR $(600$ $\left.\mathrm{MHz}, \mathrm{CD}_{3} \mathrm{OD}\right): \delta 16.5\left(\mathrm{CH}_{2}\right), 116.0(\mathrm{CN}), 123.89(\mathrm{CS}), 125.15\left(\mathrm{CCH}_{2}\right), 128.8(\mathrm{C}$ ipso to the aminothiazole), $130.22(C-m), 130.74(C-o), 131.22(C-p), 170.47\left(C \mathrm{NH}_{2}\right) . \mathrm{MS}(\mathrm{CI}+) \mathrm{m} / z(\%)$ : $215.05\left(\mathrm{MH}^{+}, 100\right)$. HRMS: calcd. for $\mathrm{C}_{11} \mathrm{H}_{9} \mathrm{~N}_{3} \mathrm{~S} 215.0517$; found 215.0519.

2-(5-Phenylthiazol-4-yl)acetonitrile (11). Compound 11 was obtained as a colorless oil in 9.5\% yield from compound $9(0.45 \mathrm{~g}, 1.5 \mathrm{mmol})$ using the reported general procedure for the synthesis of thiazoles. ${ }^{4} \mathrm{H}$ NMR (300 MHz, acetone- $\left.d_{6}\right): \delta 4.09$ (s, 2H, $\left.\mathrm{CH}_{2}\right), 7.54$ (m, 5H, $H$-aromatic), $9.04\left(\mathrm{~s}, 1 \mathrm{H}, H\right.$-thiazole). ${ }^{13} \mathrm{C} \mathrm{NMR}\left(200 \mathrm{MHz}, \mathrm{CD}_{3} \mathrm{OD}\right): \delta 19.2\left(\mathrm{CH}_{2}\right), 117.8(\mathrm{CN}), 129.09$ 130.07, 130.09 ( $C$-o, $C-m C-p$ ), 131.1, 135.9, 142.1 ( $C \mathrm{~S}, C \mathrm{CH}_{2}, C$ ipso to the aminothiazole), $153.3\left(\mathrm{CH}\right.$ thiazole). MS (CI+) $m / z(\%): 201.05\left(\mathrm{MH}^{+}, 100\right)$. HRMS: calcd. for $\mathrm{C}_{11} \mathrm{H}_{9} \mathrm{~N}_{2} \mathrm{~S}$ 201.0486; found 201.0456.

2-(5-Phenylthiazol-4-yl)acetamide (12). A solution of compound 11 (0.03 g, $0.15 \mathrm{mmol})$ in conc. $\mathrm{H}_{2} \mathrm{SO}_{4}$ was stirred at room temperature for $2 \mathrm{~h}$. To the solution was added EtOAc and concentrated ammonia was added dropwise till $\mathrm{pH} \sim 10$. the organic phase was separated, dried $\left(\mathrm{MgSO}_{4}\right)$, filtered and evaporated, to give 12 obtained as a white solid in 10\% yield, mp 209-211 ${ }^{\circ} \mathrm{C} .{ }^{1} \mathrm{H}$ NMR $\left(300 \mathrm{MHz}\right.$, acetone- $\left.d_{6}\right): \delta 3.70\left(\mathrm{~s}, 2 \mathrm{H}, \mathrm{CH}_{2}\right), 6.45$ (bs, $\left.1 \mathrm{H}, \mathrm{NH}\right), 6.97$ (bs, $\left.1 \mathrm{H}, \mathrm{NH}\right)$, 6.74(m, 3H, H-m, H-p ), 7.66(m, 2H, H-o ), 8.95 (s, $1 \mathrm{H}, H$-thiazole). ${ }^{13} \mathrm{C}$ NMR (300 MHz, 
$\left.\mathrm{CD}_{3} \mathrm{OD}\right): \delta 37.51\left(\mathrm{CH}_{2}\right), 129.2(C-p), 127.7,130.3,(C-\mathrm{o}, C-m), 132.2,135.2,147.5\left(C \mathrm{~S}, C \mathrm{CH}_{2}\right.$, $C$ ipso to the aminothiazole), $152.3\left(\mathrm{CH}\right.$ thiazole), $171.75\left(\mathrm{CONH}_{2}\right) . \mathrm{MS}(\mathrm{CI}+) \mathrm{m} / z(\%): 219.05$ $\left(\mathrm{MH}^{+}, 70\right), 202.03\left(\mathrm{M}^{+}-\mathrm{NH}_{3}, 42.6\right) 175.33\left(\mathrm{M}^{+}-\mathrm{CONH}_{3}, 65.5\right)$. HRMS: calcd. for $\mathrm{C}_{11} \mathrm{H}_{11} \mathrm{~N}_{2} \mathrm{OS}$ 219.059; found 219.054.

5-Amino-4-hydroxy-2-phenylfuran-3(2H)-one, (15a). ${ }^{12}{ }^{1} \mathrm{H}$ NMR (300 MHz, DMSO- $\left.d_{6}\right): \delta$ 5.37 (s, 1H, HC-CO), 7.34 (m, 5H, H-aromatic), 7.8 (bs, $\left.2 \mathrm{H}, \mathrm{NH}_{2}\right) .{ }^{13} \mathrm{C} \mathrm{NMR}(200 \mathrm{MHz}$, DMSO- $\left.d_{6}\right) \delta 82.6(C H-O), 111.5(C(\mathrm{OH})), 126.35(\mathrm{C}-o), 128.1(\mathrm{C}-p), 128.2(\mathrm{C}-m), 138.2(\mathrm{C}-$ ipso), $172.5\left(\mathrm{CONH}_{2}\right), 182.5$ (CO ketone).

5-Amino-2-(3-bromophenyl)-4-hydroxyfuran-3(2H)-one (15b): Compound 15b was obtained as a white solid in $77 \%$ yield from compound $\mathbf{1 4 b}$ as described, ${ }^{12} \mathrm{mp} 176-178{ }^{\circ} \mathrm{C}$. The NMR data assignment was aided by several two-dimensional spectra including COSY, HMQC and HMBC analysis. ${ }^{1} \mathrm{H}$ NMR (600 MHz, DMSO-d $)$ ): $\delta 5.44$ (s, 1H, HC-CO), 7.27 (s, 1H, OH), 7.28 (d, $J=$ $7.8 \mathrm{~Hz}, 1 \mathrm{H}, H-6), 7.36$ (t, $J=7.8 \mathrm{~Hz}, 1 \mathrm{H}, H-5), 7.43$ (s, $1 \mathrm{H}, H-2), 7.54$ (d, $J=7.8 \mathrm{~Hz}, 1 \mathrm{H}, H-4)$, 7.82 (bs, 2H, $\left.\mathrm{NH}_{2}\right) .{ }^{13} \mathrm{C}$ NMR (600 MHz, DMSO- $\left.d_{6}\right): \delta 81.9(C H-O), 111.2(C(\mathrm{OH})), 121.5$ (CBr), 125.2 (C-6), 128.6 (C-2), 130.7 (C-5), 130.9 (C-4), 138.9 (C-CH-O), $172.7\left(\mathrm{CNH}_{2}\right) 182.0$ (CO ketone). MS (CI+) m/z (\%): $270.97\left(\mathrm{M}^{+}, 31.6\right), 268.97\left(\mathrm{M}^{+}, 32.5\right), 197.96\left(\mathrm{M}^{+}-\mathrm{CO}, 66.9\right)$, $195.08\left(\mathrm{M}^{+}-\mathrm{CO}, 66.8\right), 170.97\left(\mathrm{BrBn}^{+}, 37.2\right), 168.97\left(\mathrm{BrBn}^{+}, 39.6\right)$. HRMS: calcd. for $\mathrm{C}_{13} \mathrm{H}_{6} \mathrm{NOBr} 270.963$; found 270.967.

5-Amino-2-(biphenyl-3-yl)-4-hydroxyfuran-3(2H)-one (15c). Compound 15c was obtained in $30 \%$ yield from 14c, as described, ${ }^{12} \mathrm{mp} \mathrm{164-166}{ }^{\circ} \mathrm{C} .{ }^{1} \mathrm{H}$ NMR $\left(300 \mathrm{MHz}, \mathrm{DMSO}-d_{6}\right) \delta 5.47(\mathrm{~s}$, 1H, HC-CO), 7.40 (m, 1H, H-p), 7.48 (m, 3H, H-m, H-5), 7.54 (s, 1-H, H-2), 7.64 (m, 3H, H-o, $\mathrm{H}-4), 7.86$ (bs 2H, NH$\left.H_{2}\right) .{ }^{13} \mathrm{C}$ NMR $\left(300 \mathrm{MHz} \mathrm{CDCl}_{3}\right): \delta 82.5(\mathrm{CH}-\mathrm{O}), 111.5(\mathrm{COH}), 124.8$, 125.3, 126.5, 126.7, 127.6, 129.05, 129.09, (CH aromatic), 138.0 (C-ipso CH), 139.9, $140.3(\mathrm{C}-$ ipso biphenyl, C-ipso biphenyl) $172.7\left(\mathrm{CONH}_{2}\right), 182.5$ (CO ketone). $\mathrm{MS}(\mathrm{CI}+) \mathrm{m} / \mathrm{z}(\%): 267.09$ $\left(\mathrm{MH}^{+}, 0.63\right), 250.08\left(\mathrm{MH}^{+}-\mathrm{H}_{2} \mathrm{O}, 0.42\right)$. HRMS: calcd. for $\mathrm{C}_{10} \mathrm{H}_{11} \mathrm{NO}_{2} 267.0900$; found 267.092 .

2-(Biphenyl-3-yl)-2-hydroxyacetonitrile (16c). ${ }^{15}$ Compound 16c was obtained as a byproduct in the course of the synthesis of $\mathbf{1 5 c}$ upon exposure of m-phenylbenzaldehyde to aqueous $\mathrm{KCN}$ in the presence of $\mathrm{Na}_{2} \mathrm{CO}_{3}$, glyoxal bis-(sodium hydrogen sulfate), dioxane and AcOH. After precipitation of $\mathbf{1 5 c}$, the aqueous solution was extracted with EtOAc. The organic phase was separated, dried $\left(\mathrm{MgSO}_{4}\right)$, filtered, evaporated and the residue was purified by flash chromatography to give 16c as a yellow oil in 70\% yield. The NMR data assignment was aided by several two-dimensional spectra including COSY, HMQC and HMBC analysis. ${ }^{1} \mathrm{H}$ NMR (600 $\mathrm{MHz}$, acetone- $\left.d_{6}\right): \delta 5.91(\mathrm{~s}, 1 \mathrm{H}, \mathrm{CHCN}), 6.20(\mathrm{bs}, 1 \mathrm{H}, \mathrm{OH}) 7.38(\mathrm{~m}, 1 \mathrm{H}, \mathrm{H}-p), 7.47(\mathrm{~m}, 2 \mathrm{H}, \mathrm{H}-$ $m), 7.54$ (t, $J=7.8 \mathrm{~Hz}, 1 \mathrm{H}, \mathrm{H}-5), 7.63(\mathrm{dm}, J=7.8 \mathrm{~Hz}, 1 \mathrm{H}, \mathrm{H}-6), 7.66$ (m, 1H, H-o), 7.68 (m, 1H, $\mathrm{H}-4), 7.91(\mathrm{t}, J=0.9 \mathrm{~Hz}, 1 \mathrm{H}, \mathrm{H}-2) .{ }^{13} \mathrm{C} \mathrm{NMR}\left(300 \mathrm{MHz}\right.$, acetone- $\left.d_{6}\right): \delta 63.0(C \mathrm{CN}), 120.0(\mathrm{CN})$, 125.3 (C-2), 125.8 (C-6), 127.0 (C-o), 127.2 (C-4), 127.9 (C-p), 129.3 (C-m), 129.8 (C-5), 137.9 (C-1), 141 (C-3, C-ipso biphenyl). MS (CI+) m/z (\%): $209.08\left(\mathrm{M}^{+}, 32.4\right), 183.06\left(\mathrm{MH}^{+}-\mathrm{HCN}\right.$, 100). HRMS: calcd. for $\mathrm{C}_{14} \mathrm{H}_{11} \mathrm{NO} 209.0841$; found 209.0827.

2,2-Dihydroxy-3-oxo-4-phenylbutanamide (17a). ${ }^{12} \mathrm{C} \mathrm{NMR}\left(300 \mathrm{MHz}, \mathrm{CDCl}_{3}\right): \delta 42.7$ $\left(\mathrm{CH}_{2}\right), 95.4\left(\mathrm{C}(\mathrm{OH})_{2}\right), 127.4(\mathrm{C}-p), 128.9(\mathrm{C}-m), 130.7(\mathrm{C}-o), 135.3(\mathrm{C}-\mathrm{ipso}), 172.1\left(\mathrm{CONH}_{2}\right)$, 
204.3 (CO ketone). MS (CI+) (\%): $192.067\left(\mathrm{MH}^{+}, 15\right), 174.06\left(\mathrm{M}^{+}-\mathrm{NH}_{3}, 7.5\right) 147.048\left(\mathrm{M}^{+}-\right.$ $\left.\mathrm{CONH}_{2}{ }^{+}, 100\right), 119.06\left(\mathrm{BnCO}^{+}, 16.3\right)$. HRMS: calcd. for $\mathrm{C}_{10} \mathrm{H}_{10} \mathrm{NO}_{3} 192.066$; found 192.067 4-(3-Bromophenyl)-2,2-dihydroxy-3-oxobutanamide (17b). ${ }^{12}$ Compound $\mathbf{1 7 b}$ was obtained as a pale white solid yield from compound $\mathbf{1 5 b}$ as described and was found to be mixed with residual unreacted $\mathbf{1 5 b}$. The diagnostic ${ }^{1} \mathrm{H}$ NMR peak for $15 \mathrm{~b}$ is the $\mathrm{HC}-\mathrm{CO}$ found at $5.72 \mathrm{ppm}$, whereas that of the product $\mathbf{1 7 \mathbf { b }}$ is the $\mathrm{CH}_{2}$ found at $4.08 \mathrm{ppm}$.

4-(Biphenyl-3-yl)-2,2-dihydroxy-3-oxobutanamide (17c). ${ }^{12}$ Compound $17 \mathrm{c}$ was obtained as a pale yellow solid in $35 \%$ yield from compound $15 \mathrm{c}$ as described, ${ }^{12} \mathrm{mp} 90-92{ }^{\circ} \mathrm{C} .{ }^{1} \mathrm{H}$ NMR $(300$ $\mathrm{MHz}$, acetone- $\left.d_{6}\right): \delta 4.11\left(\mathrm{~s}, 2 \mathrm{H}, \mathrm{CH}_{2}\right), 6.15(\mathrm{bs}, 1 \mathrm{H}, \mathrm{OH}) 7.2(\mathrm{bs}, 1 \mathrm{H}, \mathrm{NH}), 7.34(\mathrm{~m}, 9 \mathrm{H}, H$ aromatic, $\mathrm{NH}) .{ }^{13} \mathrm{C}$ NMR (300 MHz, $\left.\mathrm{CD}_{3} \mathrm{OD}\right): \delta 41.4\left(\mathrm{CH}_{2}\right), 97.3\left(\mathrm{C}(\mathrm{OH})_{2}\right), 123.8,125.4,125.7$, 127.0, 127.12, 127.15, 127.27 (CH-aromatic), 133.3 (C-ipso to the methylene), 139.7, 137.9 (Cipso to the biphenyl), $169.8\left(\mathrm{CONH}_{2}\right), 202.1$ (CO ketone). $\mathrm{MS}(\mathrm{CI}+) \mathrm{m} / z(\%): 267.09\left(\mathrm{M}-\mathrm{H}_{2} \mathrm{O}\right.$, 7.4), 212.06 (Ph-Bn-COOH, 40.6). HRMS: calcd. for $\mathrm{C}_{16} \mathrm{H}_{13} \mathrm{NO}_{3}$ 267.090; found 267.093.

3-Hydroxy-2-oxo-4-phenylbut-3-enamide (18a). ${ }^{12}$ Compound 18a was obtained as a pale yellow solid in $93 \%$ yield upon evaporation of a solution of $\mathbf{1 7 a}$ in acetone. ${ }^{1} \mathrm{H}$ NMR $(300 \mathrm{MHz}$, acetone- $\left.d_{6}\right): \delta 7.06\left(\mathrm{~s}, 1 \mathrm{H}\right.$, enol), $7.36(\mathrm{~m}, 3 \mathrm{H}, \mathrm{H}-m, \mathrm{H}-p), 7.93(\mathrm{~m}, 2 \mathrm{H}, o) .{ }^{13} \mathrm{C} \mathrm{NMR}(300 \mathrm{MHz}$, $\left.\mathrm{CDCl}_{3}\right) \delta 118.8$ (CH enolic), 128.5 (C-m), 128.8 (C-p), 130.7 (C-o), 134.6 (C-ipso), 146.9 (COH enolic), $165.3\left(\mathrm{CONH}_{2}\right), 184.6$ (CO ketone).

4-Benzyl-1H-imidazole-5-carboxamide (20a). A solution of $17 \mathbf{a}(0.1 \mathrm{~g}, 0.34 \mathrm{mmol})$ hexamethylenetetramine $(0.1 \mathrm{~g}, 0.69 \mathrm{mmol}), \mathrm{NH}_{4} \mathrm{OAc}(0.026 \mathrm{~g}, 0.34 \mathrm{mmol})$ in acetic acid $(1.5$ $\mathrm{mL}$ ) was heated with stirring at $165^{\circ} \mathrm{C}$ for $5 \mathrm{~min}$ under microwave irradiation conditions. The mixture was poured into a saturated aqueous $\mathrm{NH}_{4} \mathrm{OH}$ solution cooled to $0{ }^{\circ} \mathrm{C}$. The brown precipitate formed was filtered and the filtrate was extracted with EtOAc. The organic phase was dried $\left(\mathrm{MgSO}_{4}\right)$, filtered and evaporated to give a brown residual oil which was purified by flash chromatography (EtOAc). Compound 20a was isolated as white needles (crystallized from acetone) in $4 \%$ yield (microwave irradiation) or $7 \%$ yield (thermal conditions, $1 \mathrm{~h} 165{ }^{\circ} \mathrm{C}$, using the same workup). ${ }^{1} \mathrm{H}$ NMR (600 MHz, acetone- $\left.d_{6}\right): \delta 4.48\left(\mathrm{~s}, 2 \mathrm{H}, \mathrm{CH}_{2}\right), 6.28(\mathrm{bs}, 1 \mathrm{H}, \mathrm{NH}), 7.15$ (bs, 1H, NH), 7.16 (t, $J=7.2 \mathrm{~Hz}, 1 \mathrm{H}, \mathrm{H}-p), 7.25(\mathrm{t}, J=7.2 \mathrm{~Hz}, 2 \mathrm{H}, \mathrm{H}-m), 7.3(\mathrm{~d}, J=7.2 \mathrm{~Hz}, 2 \mathrm{H}$, $\mathrm{H}-o$ ), 7.50 (s, $1 \mathrm{H}, \mathrm{CH}$-imidazole). ${ }^{13} \mathrm{C} \mathrm{NMR}\left(600 \mathrm{MHz}\right.$, acetone- $\left.d_{6}\right): \delta 30.3\left(\mathrm{CH}_{2}\right), 126.0(C-p)$, $128.2(\mathrm{C}-m), 128.5(\mathrm{C}-o), 130.4(\mathrm{C}-m), 138.2$ (C-ipso), $133.5\left(\mathrm{CH}\right.$ imidazole), $133.7\left(\mathrm{CCONH}_{2}\right)$ $139.6(\mathrm{Bn}-\mathrm{C}), 165.2\left(\mathrm{CONH}_{2}\right)$. MS $(\mathrm{CI}+) m / z(\%): 202.10\left(\mathrm{MH}^{+}, 4\right), 185.068\left(\mathrm{MH}^{+}-\mathrm{NH}_{3}\right.$, 2), $159.10\left(\mathrm{MH}^{+}-\mathrm{CONH}_{3}, 0.81\right)$. HRMS $\left(\mathrm{MH}^{+}\right)$: calcd. for $\mathrm{C}_{11} \mathrm{H}_{12} \mathrm{~N}_{3} \mathrm{O} 202.098$; found 202.097 .

4-(Biphenyl-3-ylmethyl)-1H-imidazole-5-carboxamide (20c). Compound 20c prepared from 17c-18c was isolated as described for $\mathbf{2 0 a}$, as a yellow oil in 7\% yield (microwave irradiation or thermal conditions) from 17c. ${ }^{1} \mathrm{H} \mathrm{NMR}\left(300 \mathrm{MHz}\right.$, acetone- $\left.d_{6}\right): \delta 4.50\left(\mathrm{~s}, 2 \mathrm{H}, \mathrm{CH}_{2}\right), 6.2(\mathrm{bs}, 1 \mathrm{H}$, $\mathrm{NH}), 7.11$ (bs, 1H, NH), 7.34 (m, 3H, H-aromatic), 7.42 (m, 3H, H-aromatic), 7.51 (s, 1H, CHimidazole), $7.62\left(\mathrm{~m}, 3 \mathrm{H}, \mathrm{H}\right.$-aromatic). ${ }^{13} \mathrm{C} \mathrm{NMR}\left(300 \mathrm{MHz}\right.$, acetone- $\left.d_{6}\right): \delta 31.3\left(\mathrm{CH}_{2}\right), 125.6$, $127.7,128.10,128.16,128.56,129.63,129.77$ (CH-aromatic) $134.33,134.55\left(\mathrm{CCONH}_{2}, \mathrm{CH}-\right.$ imidazole). At the concentration of the sample, the quaternary $\left(C \mathrm{CONH}_{2}\right.$ and $\left.\mathrm{CCH}_{2}\right)$ were not observed. 


\section{Acknowledgements}

We gratefully acknowledge the "Marcus Center for Pharmaceutical and Medicinal Chemistry" at Bar Ilan University.

\section{References}

1. The Merck Index, 14th Ed., Merck \& Co. Inc., NJ, USA, 2006.

2. Yasuda, N.; Iwagami, H.; Nakanishi, E.; Nakamiya, T.; Sasaki, Y.; Murata, T. J. Antibiot. 1983, 36, 242.

3. Shealy, Y. F.; Krauth, C. A.; Montgomery, J. A. J. Org. Chem. 1962, 27, 2150.

4. Herschhorn, A.; Lerman, L.; Weitman, M.; Gleenberg-Oz I.; Nudelman, A.; Hizi, A. J. Med. Chem. 2007, 50, 2370.

5. Bredereck, H.; Theilig, G. Chem. Ber. 1953, 86, 88.

6. (a) Noriaki, M.; Naoshi, K.; Sadao, H.; Takashi, S.; Arihiro, K.; Naoko, A.; Yoshihito, U.; Akira, M.. J. Am. Chem. Soc. 2003, 125, 9970; (b) Wanner, J. M.; Koomen, G.-J. J. Chem. Soc., Perkin Trans. 1 2002, 16, 1877.

7. Baldwin, J. J.; Lumma, P. K.; Novello, F. C.; Ponticello, G. S.; Sprague, J. M.; Duggan, D. E. J. Med. Chem. 1977, 20, 1189.

8. Kortekaas, T. A.; Cerfontain, H. J. Chem. Soc., Perkin Trans. 2 1979, 2, 224.

9. Masayuki, S.; Hiromichi, O.; Sachiko, K.; Tetsuzo, K. Chem. Pharm. Bull. 1984, 32, 3848.

10. Foehlisch, B.; Wolf, E. J. Chem. Res., Synop. 1983, 7, 166.

11. Grimmett, M. R. Adv. Heterocycl. Chem. 1970, 12, 104.

12. (a) Dahn, H.; Rotzler, G. J. Org. Chem. 1991, 56, 3080; (b) Dahn, H.; Rotzler, G. Helv. Chim. Acta 1960, 43, 1555.

13. Nishimura, K.; Kitajima, K. J. Org. Chem. 1979, 44, 818.

14. Wolkenberg, S. E.; Wisnoski, D. D.; Leister, W. H.; Wang, Y.; Zhao, Z.; Lindsley, C. W. Org. Lett. 2004, 6, 1453.

15. Plummer, E. L.; Pincus, D. S. J. Agric. Food Chem. 1981, 29, 1118. 